\title{
THE QUALITY OF EDUCATIONAL OUTCOMES OF EGYPTIAN UNIVERSITIES Hadier Mohamed Mohamed Shafiq
}

\section{Introduction:}

Quality of education outputs in all its stages and its correlation with the high demand for skilled personnel considered as significant prerequisites for enabling technology and development. Comprehensive education creates individuals with high skills who acquire good jobs with higher wages, better earnings and better life.

Nevertheless, international documents indicated declining in the competitiveness of the Egyptian economy, on the one hand, and Egypt's ranking in the Total Quality Measurement of its educational system to rank 131 out of the 139 countries; as stated in the Egyptian competitiveness Eighth report for the year 2012 (Al Badawi, p.7)

As per the above and as a confirmation of importance of the quality of university student in Egypt, the idea of this research occurred attempting to shed light on meaning of University Student's Quality and its consequences.

\section{Study Problem}

In Egypt; University Education faces many problems and difficulties, which are obstacles that prevent universities from reaching their desired performance in supporting the development of their societies. Hence there is continuous growth in university education, its fields and steady increase of enrolled students; problems related to lack of capabilities of governmental and private universities rises, especially the accommodation all applied students and meeting the increased necessities to update its syllabus and systems. It is all coincides with high costs of educational services, at all levels, while increases the burdens pressure on the public budget. Additional to that the poor quality of graduates and the retreat of their opportunities against the intensification of international competition not only in foreign manpower markets, but in some case the Egyptian manpower markets also. (Al Badawi: 2005, p.5)

Accordingly, this research's problem appeared from the following question:

To what extent do universities and quality indicators of educational product concurs?

\section{Research Objectives}

This research is an attempt to determine the following:

1. The Relationship between Educational Process and Productive Process.

2. Importance of Educational Products' Quality.

3. Observation of university students' capabilities.

\section{Importance of Research}

The importance of this research that it focuses on the concept of educational product quality in order to clarify the impact of university student's quality and its reflection on the market requirements. However, the importance of this research concluded in the following points:

1. To emphasize the university education role and quality.

2. To clarify the relationship between educational process and productive process.

3. To identify university students level of capabilities.

\section{Methodology:}

This research is a perusal attempt to quality of education product concepts within university system as a product delivered by Ministry of Higher Education to the manpower market. Therefore, this research follows the descriptive approach 
by linking certain related terms and concepts through quality as access to performance of the entry work, which requires the modernization of traditional administrative methods and collective work of system members.

\section{Research Terminology}

1) The educational product is "a statement meaning what the learner expects to know, understand and / or be able to demonstrate at the end of the learning period" (Zahrani, Gosling and the Moon, 2001, p. 26)

2) Quality of the Educational Product is the product that achieves and exceeds the expectations of the consumer and conformity of this product to the specifications specified during the design i.e. the degree of meeting the requirements expected by the service beneficiary or those agreed upon (Quality and Accreditation Dictionary 2007, p. 17)

\section{Theoretical framework}

\section{Preface:}

Universities role is no longer concentrated in the academic educational role only, but it is about sharing knowledge investment with the private and government sectors through marketing the university's knowledge products through studies, research and consulting work. It is about selecting technology, systems tools, training and qualification of manpower forces to enter the production process and increasing of performance factors of production (capital, land, work, organization), all through raising the efficiency of the educational product and its rapid response to the requirements and needs of the market, which are issues of concern to the state.

Thus, the concept of productivity from university education has become one of the basic concepts that play an important role in the industrial societies (Bydanova: 2008, p.2), which aims to obtain qualified learners who contribute to national development by applying standards and values that satisfy the accreditation and quality bodies to match the Modern market and align with the progress in technical education and gain skilled knowledge by easiest ways on the other hand. (Akhader: 2007, p.7)

Hence, expansion of university education has become the dominant trend in most countries as the main channel for graduation of manpower that prepared to enter world of production and intensive knowledge services. Whereas, with the development of the manpower market will lead to further the necessity of providing university education opportunities. Some research estimated that the need for an individual who rises in the manpower market ladder requires university education at least once a week (Ammar: 2009, p. 21).

It was therefore necessary to identify the educational product and its relationship to educational quality, through the following axes:

1. Educational process is a productive process.

2. Quality of educational outputs.

3. Reality of the capabilities of university students.

First: The Educational Process is a Productive Process:

Education is considered a service provided by the state to citizens as a right; people have come to view it as a productive and investment process that contributes to building a new capital called human capital (HC) to distinguish it from physical capital. However, it is more productive with highest return (Rashdan, 2015, p. 237).

The Productivity is defined as the largest proportion of outputs of a given input value, which is an indicator that measures the different production capacity to achieve certain level of output relative to the inputs that have been invested 
(www.mne.gov.ps/MneModules/studies/Pr oductivity.pdf , P1)

Productivity is the key determinant of long-term income growth, and any lowincome, low-skill and low-productivity development strategy is not sustainable in the long term and does not match to poverty improvement where, the investment in education and skills helps to make an economy centered around activities of Higher value input and dynamic growth sectors (International Labor Office: 2008, p. Vii)

As a result, the production process can be defined from an economic point of view as a process of production, defined as a set of inputs that changes and adapts to reach the required product. However, this process is different from that of dealing with human capital therefore handling it needs to clarify how to deal with the inputs to access outputs.

"Educational Productivity" term was define as measurement use to calculate the gain and loss in its final form which required knowing the amount of money invested in education and the amount of its return (Rashdan: 2015, p.262) and it deals with the relationship between educational inputs and outputs. Education inputs include all elements contributed to education such as buildings, equipment, tools, students, teachers, management, application and programs. Whereas, the outputs include successful students and professional growth. (Mursi: 1993, p. 260)

Educational Productivity is divided into two parts (Al-Rashdan 2001, pp. 240243):

A. Internal productivity, which is the extent to which the educational system is capable of performing expected roles, it includes all human elements within the system, educational programs, curricula, technology and activities, which in turn contain two types:
1. Quantitative productivity which means to produce as many graduates as possible.

2. Quality productivity, which means the quality of graduates from universities.

B. External productivity, which means the ability level of Higher Education Institutions to achieve the community goals, which developed the system for its service, through graduates who contribute in different fields efficiently and leads to satisfaction of manpower market for these graduates.

As mentioned previously, education has become a major industry around the world, which appears in the increase in investment allocated to education funding. The Educational Efficiency relation to the economic value of education has a great importance to the economic efficiency of different countries. This means to obtain the greatest educational output with the largest economy of inputs with less effort and money and as quickly as possible that emphasizes the link between productivity and educational productivity closely (Rashdan, 2015, p. 238)

The concept of the educational product requires several conditions represented in clarity of institution mission and its educational objectives, the adequacy of resource inputs, the organization of resources available in accordance with its purposes and in an effective way to achieve the objectives set, structural feedback and teaching faculty members to know the quality of performance of targeted educational processes and arrangements to assess the satisfaction of graduates and employers.(OECD and World Bank: 2010, p.170). 
However, under the modern concept
of quality assurance of university
education, which is largely based on the
need to select satisfactory levels of
performance, the outputs of education are
defined as "skills and knowledge levels
that are acquired by the student after
studying the course or educational
program such as information and cognitive
skills or transferable skills Learning other
areas of knowledge "(Quality Assurance
and Accreditation Center, 2009, p.15), and
therefore we had to address the next axis.
Second: Quality of Educational
Outputs:
The term "Quality" has been found in the manpower and business market, which is related to the pursuit of upgrading the product based on several factors that are produced by scientific theories and research assertions, which in turn are the result of high quality treatment (Obaid, 2012, p.19).

What have been produced from the quality management systems in the productive institutions resulted in improving their products and gaining the satisfaction of the beneficiaries. Hence, it was necessary to spread them and spread them to educational institutions, which was reflected in the importance of quality in higher education within the decisions of international, regional and local conferences and events. (Banajah and Muqbal: 2010, p.3)

Therefore, the quality of educational process outputs can be described as the strategy that aims to employ the information, skills and abilities to achieve continuous improvement, thus contributing to improvement of community institutions value. The quality thus emerges through integrated interaction between outputs of educational process from accumulated disciplines, experience and knowledge performed by different organizations and sectors according to their orientation and philosophy (2000, p.76: Haksen \& others).
Accordingly, quality of university education means "the ability of the total characteristics and advantages of educational product to meet student, manpower market, society, internal and external beneficiaries' requirements." (Abdelfattah, 2000, p. 73)

It is also defined as all that leads to development of intellectual and fictional abilities of students, improve their level of understanding, raise their skills in resolution of all issues and consideration of things through what they have learned in the past and what they are currently studying via a curriculum that helps to stimulate Students' natures of creativity, inquiry and analysis encouraging them to be independent in their choices by expressing their opinions and ideas through importance of self-criticism in the process of education (Bridge: 2004, p. 80).

Therefore, the Total Quality Management Guide to Higher Education in Arab World may require some of criteria of output (Al-Obeidi: 2009, p. 12) as follows:

- Institutions of higher education Outputs should be compatible with goal of education and its objectives.

- Ensure that the quality of output focus on the learner in terms of cognitive, psychological, social and cultural.

- Achieving the quality of the university product is not in isolation from need to achieve it in preuniversity education, due to close correlation between outputs of public education and outputs of higher education in general and university education in particular.

Therefore, Ministry of Higher Education in Egypt has emphasized the need to pay attention to quality of education and its outputs in light of continuing political trends to raise absorptive capacity in higher education system and to accept all successful 
graduates of secondary education (Al biblawi 2008: 257).

However, despite all the initiatives taken by Egypt, most studies indicate that non-alignment of the outputs of university education to the needs of Manpower market is one of biggest challenges facing Egyptian university education since it affects various aspects of economic, social life and achievement of development objectives which leads to waste of energies Human resource reduction and poor investment in human development, then are reflected in the overall development (Ahmed: 2014, p.3).

Reason for this problem is that it is not clear that quality is concerned with measurement of educational outcomes through achievements and exploitation of their sources, on the one hand, and measuring same goals as inputs on the other hand. (Hilali: 2001, p. 200)

Therefore, the problem of the quality of the educational product is reflected in the concept of measuring that product as it is not limited to students who complete the education stage, but also includes many things related to the quality of education and its impact on the students themselves and their surroundings (Hilali 2009, p. 691).

Henceforth, the approaches taken by the countries to achieve quality of university education differed but agreed on the need to measure educational product through professional evaluation and satisfaction rates for students as a process in which the society invests its resources for improvement, innovation and value added evaluation (Dew: 2009, p.2).

Third: Reality of University Students' Abilities:

Higher education institutions are institutions with a wide variety of outputs, which are main means for advancement and prosperity of any society in the world. The outputs of educational process are expanded according to requirements of rapidly changing external environment, making them more diverse and comprehensive (p.8). That these institutions are still unable to link the policies of admission and enrollment in institutions of higher education to the needs of manpower market jobs and harmonization of disciplines available in these institutions and their counterparts in manpower market "(Zahrani, 1423, p. 28)

University institutions face challenges to low quality of their outputs and lack of harmony with manpower market and development plans needs that many of specializations and programs of these institutions are no longer a priority for community needs and manpower market is saturated both locally and globally. The output of university education is suffering from unemployment especially in fields of humanities and social sciences. The government was burdened with employing these outputs, but private sector required availability of some other skills which led to the gap between supply and demand. (Al-Obeidi: 2009, p.3)

With presence of this gap between university education outputs and manpower market requirements, there has been an ongoing complaint about low level of university graduates, especially in applied disciplines, in addition to large surplus of graduates in some disciplines such as commercial and law, which is met by shortage of qualified graduates in scientific disciplines leading to weakness of relation between Egyptian university education policy and development plans in society (Abdin: 2003, p. 288).

Al Turkestani in 1998, in his study entitled "Role of Higher Education in Meeting Needs of Saudi Manpower Market", he emphasized that reasons for local manpower market not accepting outputs of higher education and the responsibility for non-alignment of outputs 
of higher education and the manpower Market requirements.

$\mathrm{He}$ identified them in four main reasons that prevent manpower market to accept the outcomes of education, which is behavioral aspect of students towards work that needs to reconsider admission policy of students in universities. Then comes academic side, which depends on some university professors on one hand and students on other hand, where they needs to develop their individual skills which is the starting point for the third reason, individual abilities. The fourth reason is related to wages; the responsibility of the official bodies who need to clarify benefits obtained by graduates and eliminate large differences in wages between establishments so that it does not affect manpower market.

Al-Humaidi and others research 1999, entitled "Higher Education Patterns in Gulf Cooperation Council Countries", which showed that proportion of specialists in theoretical and educational studies constitute about $85 \%$ of graduates, and that these graduates did not return to manpower market in the private sector, Quality of university graduates, which required institutions of higher education need to coordinate with the requirements of the labor market and keep abreast of changes and requirements.

As mentioned previously and other studies, it is possible to identify some of the problems and challenges that help to exacerbate this gap, through internal audit of project of quality assurance and accreditation in 2007, which concluded that (Ministry of Higher Education, 2008):
A. Graduates show insufficient work. personal skills in subjects and
B. That current academic program constitutes an insufficient basis for action.
C. There is insufficient faculty commitment to teaching and

\begin{abstract}
learning methods that enable students to achieve targeted learning outcomes by providing course specifications and informing students of evaluation criteria.
\end{abstract}

Al-Khouri summarized the causes of this gap in five areas: professional and knowledge specialization, structural level of job, level of salary and bonus, psychological desire and social outlook, and finally outputs of the educational process (2013, p. 28)

In precise look at Egyptian universities reality, some problems have been found to aggravate the crisis of university education in Egypt in light of the global competition including the following:

* Universities admission policy which varies according to the increase in application numbers gave the opportunity to those of low scientific level to join the universities which led to the decline of scientific and moral level in Egyptian universities (Basiony: 2015, p. 242).

* In spite of the fact that university's role in terms of intellectual, cognitive, educational and research is almost the agreed globally but this reality did not reflect the procedural goals of university education system in Egypt. It did not include knowledge, education, community specific, declared, measurable, monitoring and evaluation goals neither nationally nor single institution level. The main goal of government universities is simply to accommodate students as best they can to graduate them of any quality (National Specialized Councils 2013, p. 290). 


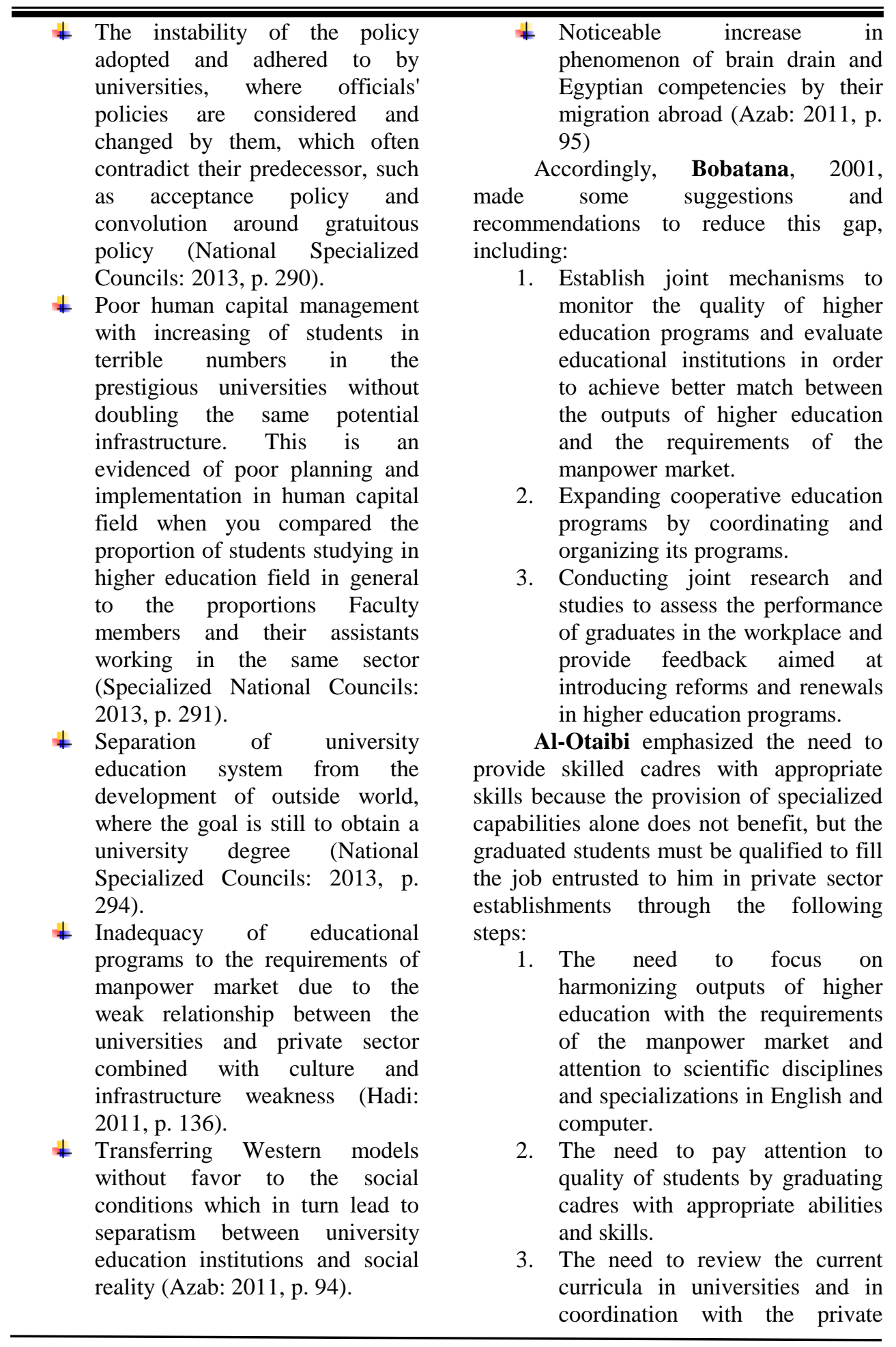




\section{sector in the development of educational plans. \\ 4. Involve the private sector in studies conducted to know the requirements of manpower market. \\ 5. The educational institutions should transfer the field modern work trends to its internal systems so that the private sector will not need to modify, refine and renew graduates skills.}

\section{Conclusion:}

Egyptian university establishments should be able to prepare its graduates to be capable of facing the society changed challenges. Therefore, these educational institutions must integrate with each other through competition and cooperation between their departments, colleges and institutes and work for the benefit of society.

With rapid changes experienced by University education through emergence of different educational systems, we recognize the tragedy of the inadequacy and ability of the graduate to enter the manpower market and identify its destination in Egyptian universities.

Therefore, it is necessary to consider the university education system by achieving quality objectives and clarifying the concept of the quality of the educational product, which refers to the university student's conformity to specifications of the global and local market as the main pillar in building and advancement of Egyptian society.

This research is an attempt to read the relation between concept of productivity and quality of educational product, in which the research refers to some variables among university students.

\section{Summary:}

Quality of education outputs in all its stages and its correlation with the high demand for skilled personnel considered as significant prerequisites for enabling technology and development.

Comprehensive education creates individuals with high skills who acquire good jobs with higher wages, better earnings and better life.

Accordingly, it must to answer "To what extent do universities and quality indicators of educational product concurs?, which explain universities role about sharing knowledge investment with the private and government sectors through marketing the university's knowledge products through studies, research and consulting work. It is about selecting technology, systems tools, training and qualification of manpower forces to enter the production process and increasing of performance factors of production, all through raising the efficiency of the educational product and its rapid response to the requirements and needs of the market, which are issues of concern to the state.

Through the shown axis:

First: The Educational Process is a Productive Process:

The axis which explains the Education process as a production production, defined as a set of inputs that changes and adapts to reach the required product. However, this process is different from that of dealing with human capital therefore handling it needs to clarify how to deal with the inputs to access outputs.

However, this definition is largely based on the need to select satisfactory levels of performance; the outputs of education are defined as "skills and knowledge levels that are acquired by the student after studying the course or educational program such as information and cognitive skills or transferable skills learning other areas of knowledge"

Second: Quality of Educational Outputs:

The axis which explains the quality of educational process outputs can be described as the strategy that aims to 
employ the information, skills and abilities to achieve continuous improvement, thus contributing to improvement of community institutions value. The quality thus emerges through integrated interaction between outputs of educational process from accumulated disciplines, experience and knowledge performed by different organizations and sectors according to their orientation and philosophy.

Therefore, Ministry of Higher Education in Egypt has emphasized the need to pay attention to quality of education and its outputs in light of continuing political trends to raise absorptive capacity in higher education system and to accept all successful graduates of secondary education.

However, despite all the initiatives taken by Egypt, most studies indicate that non-alignment of the outputs of university education to the needs of Manpower market is one of biggest challenges facing Egyptian university education since it affects various aspects of economic, social life and achievement of development objectives which leads to waste of energies Human resource reduction and poor investment in human development, then are reflected in the overall development.

Therefore, the problem of the quality of the educational product is reflected in the concept of measuring that product as it is not limited to students who complete the education stage, but also includes many things related to the quality of education and its impact on the students themselves and their surroundings.

\section{Third: Reality of University Students'} Abilities:

University institutions face challenges to low quality of their outputs and lack of harmony with manpower market and development plans need that many of specializations and programs of these institutions are no longer a priority for community needs and manpower market is saturated both locally and globally. The output of university education is suffering from unemployment especially in fields of humanities and social sciences. The government was burdened with employing these outputs, but private sector required availability of some other skills which led to the gap between supply and demand. (Al-Obeidi: 2009, p.3)

Therefore, it is necessary to consider the university education system by achieving quality objectives and clarifying the concept of the quality of the educational product, which refers to the university student's conformity to specifications of the global and local market as the main pillar in building and advancement of Egyptian society.

This research is an attempt to read the relation between concept of productivity and quality of educational product, in which the research refers to some variables among university students.

\section{List of references}

1. Ahmed, Naima Mohamed (2014) Adapting the Output of Higher Education to the Needs of the Labor Market, Analytical Applied Study, Working Paper for Participation in the Third International Conference: Integration of Education Outputs with the Public and Private Sector Labor Market, 28 April - 1 May, Jalwan, Amman - Jordan

2. Green, Faiza Bint Mohammed Bin Hassan (2007) Problems of Achieving Quality in General Education (An Analytical Descriptive Study), paper presented to the 2nd National Conference on Quality, "Work Environment and Quality Culture: A Vision for a Promising Future", February 12-14.

3. Badawi, Asmaa: Higher Education in Egypt (2012) Is Freeism Fair to Equal Opportunities? , Cairo, International Population Council. 
4. Al-Bassiouni, Ahmed Dweidar (October, 2015) Education in Egypt, Cairo, Al-Ahram Center for Publishing.

5. Bubtana, Abdullah (2001) Activating Cooperation between Higher Education and Business Sector, Riyadh, Arab Bureau of Education Press for the Gulf States.

6. Biblawi, Hassan Hussein and others (2008) Editing, Taima, Roushdi Ahmed: Total Quality in Education "Between the two indicators of excellence and standards of accreditation foundations and applications", Dar Al-Masirah: Amman (Jordan), 2.

7. Turkistani, Habibullah Mohammed (22-25 February 1998) The Role of Higher Education in Meeting the Needs of the Saudi Labor Market, Paper presented to the Higher Education Symposium in Saudi Arabia (Future Perspectives) 25-28 Shawwal 1418H.

8. The Bridge, Samir (2004) Reorganization of Higher Education, paper presented at the workshop organized by the Ministry of Education and Higher Education, Beirut, Directorate General of Higher Education.

9. Al-Humaidi, Abdulrahman Saad et al. (1999) Patterns of Higher Education in the Arab Gulf Cooperation Council Countries, Riyadh, Al-Imam Muhammad Bin Saud Islamic University Press.

10. Al-Khoury, Ali Mohamed (September 2013) Localization between Supply and Demand A Study of the Reality of Emiratization in Arab Countries and its Requirements - Strategic Vision, Emirates Identity Authority.

11. Daoud, Ibrahim Dawood (2007) in the book of administrative and educational system in Saudi Arabia.
12. Al-Rashdan, Abdullah Zahi (2015) Economics of Education, Wael Publishing House, Amman.

13. The Economist and Others, Mohsen (2012) Measuring the Quality of Higher Education Outputs from the Perspective of Universities and Some Labor Market Institutions Analytical Study in the Middle Euphrates Region, Journal of Management and Economics, Year 34, Issue 90.

14. Abdeen, Mahmoud Abbas (April, 2003) Issues of Education Planning and Economics between Global and Local, Cairo, Egypt-Lebanon.

15. Abdel-Fattah, Nabil Abdel-Hafiz (2000) Total Quality Management and its Expected Role in Improving Productivity, Administrative Journal, Institute of Public Administration, Muscat, Year (22), No. 82.

16. Obaid, William Taoudros (2012) Eyes of Reason, Journal of Research and Studies of the Quality of Education, National Authority for Quality Assurance of Education and Accreditation, No. 1.

17. Al-Obeidi, Ceylan Jubran (6-10 December 2009) Ensuring the Quality of Higher Education Outputs in the Context of Community Needs, Working Paper for the Twelfth Conference of Ministers Responsible for Higher Education and Scientific Research in the Arab World, entitled "Harmonization of Higher Education Outputs and Community Needs in the Arab World" Culture and Science, Beirut.

18. Al-Otaibi, Munir Batani (March 2010) "The Relevance of Higher Education Outputs to the Needs of the Saudi Labor Market", Analytical Study, Educational Journal, Kuwait, Scientific Publishing Council, No. 94,

19. Azab, Mohamed Ali (2011) University Education and 
Development Issues, Cairo, AngloEgyptian.

20. Ammar, Hamid (2009) Towards a Vision for the University of the Future, a conference entitled "The Future of Arab University Education, Development Perspectives", Part I Ain Shams University, Arab Center for Education and Development.

21. Quality and Accreditation Dictionary: Quality Assurance Center, Alexandria University, www.pdffactory.com

22. Mursi, Mohamed (1993) Educational Administration, Its Origins and Applications, World of Books Cairo.

23. Organization for Economic Cooperation and Development and the World Bank (2010) Review of Higher Education Policies in Egypt.

24. Encyclopedia of National Specialized Councils (2013) Annual Book 2012/2013, Volume 39.

25. Al-Hadi, Sharaf Ibrahim (2011) A Strategic Vision for Arab
Universities with High Educational Quality and Low Expenditure, Journal of Psychological and Educational Research, No. 1, Year 26.

26. Hilaly, El-Sherbini El-Helaly (2009) Recent trends in the efficiency of the university educational process from the economic perspective, a conference entitled "The Future of Arab University Education, Development Perspectives", Part I Ain Shams University, Arab Center for Education and Development.

27. Bydanova, Elisaveta (18-20 march 2008) Graduate employability in transitional economy, international labor process conference "work matters", Dubline, Ireland.

28. Haksen \& others (2000) "Service management and operations", 2ns edition, prentice-hall upper saddle river, new jersey 